\title{
Antibacterial Effect of Aloe Vera Gel Extract on Escherichia coli and Salmonella enterica Isolated from the Gastrointestinal Tract of Guinea Fowls
}

\author{
Frederick Adzitey $^{1 *}$, AnthonyAmisson Agbolosu ${ }^{2}$ and Udoji James Udoka ${ }^{1}$ \\ ${ }^{1}$ Department of Veterinary Science, University for Development Studies, Box TL 1882, Tamale, Ghana \\ ${ }^{2}$ Department of Animal Science, University for Development Studies, Box TL 1882, Tamale, Ghana \\ *Corresponding author's Email: adzitey@yahoo.co.uk; ORCID: 0000-0002-8814-0272
}

\begin{abstract}
Aloe vera has a long history as a medicinal plant with diverse therapeutic applications. This study was conducted to assess the antibacterial effect of Aloe vera gel extract against Escherichia coli and Salmonella enterica isolated from the gastrointestinal tract (GIT) of guinea fowls. The conventional method was used for the isolation of Escherichia coli and Salmonella enterica. The antibacterial activity of Aloe vera gel extracts (50, 100 and $200 \mathrm{mg} / \mathrm{ml})$ and standard antibiotics were evaluated using the disk diffusion method. The prevalence of Escherichia coli in the GIT of the guinea fowls was $100 \%$ (15/15). All the Escherichia coli were susceptible to ciprofloxacin. At $48 \mathrm{~h}$ and $72 \mathrm{~h}$ of incubation, all the Escherichia coli were susceptible to gentamicin but not at $24 \mathrm{~h}$. Inhibition zones using the Aloe vera gel extract ranged from $7.87-12.23 \mathrm{~mm}(50 \mathrm{mg} / \mathrm{ml}), 8.53-17.23 \mathrm{~mm}(100 \mathrm{mg} / \mathrm{ml})$ and $7.43-10.67 \mathrm{~mm}(200$ $\mathrm{mg} / \mathrm{ml}$ ) for Escherichia coli. Also, antibacterial test for Escherichia coli using the Aloe vera gel extract revealed an inhibition zone of 9.10-12.23mm for Escherichia coli isolate GIT1, 7.8-8.57mm for Escherichia coli isolate GIT2 and 7.43-17.23mm for Escherichia coli isolate GIT7. The prevalence of Salmonella enterica in the GIT of the guinea fowls was $40 \%$ (6/15). All Salmonella enterica were susceptible to gentamicin. At $48 \mathrm{~h}$ and $72 \mathrm{~h}$ of incubation, all the Salmonella enterica were susceptible to suphamethoxazole/trimethoprim and tetracycline but not at $24 \mathrm{~h}$. Inhibition zones using Aloe vera gel extract ranged from 7.13-12.57mm (50 mg/ml), 4.2-6.7mm (100 mg/ml) and $0-9.23 \mathrm{~mm}(200 \mathrm{mg} / \mathrm{ml})$. Furthermore, antibacterial test for Salmonella enterica using the Aloe vera gel extract revealed an inhibition zone of 5.3-12.57mm for Salmonella enterica isolate GIT9, 0-7.8mm for Salmonella enterica isolate GIT10 and 4.2-9.0mm for Salmonella enterica isolate GIT15. The study revealed that Aloe vera gel extract possessed antibacterial properties. Therefore, it can be added to the feed of guinea fowls as a prophylactic to reduce bacterial infections.
\end{abstract}

Key words: Aloe vera, Antibiotics, Escherichia coli, Gut, Salmonella enterica

\section{INTRODUCTION}

Avian pathogenic Escherichia coli strains can cause avian colibacillosis in guinea fowls. Colibacillosis is characterized by colisepticemia, hemorrhagic septicemia, coligranuloma, and chronic respiratory disease, which contributes to economic losses for the world's poultry industries (Nolan et al., 2013). Salmonella enterica causes salmonellosis in guinea fowl. Salmonella enterica serovars Pullorum and Gallinarum are particularly involved in poultry salmonellosis. They can cause death in chicks, poults and adult poultry. Poultry including guinea fowls infected with Salmonella enterica huddle near a heat source are anorectic, appear weak and have whitish diarrhoea around the vent. They also show symptoms of fever, are pale, dehydrated, have diarrhea, swollen liver, brittle and often bile-stained (Schepop, 2017).

Escherichia coli and Salmonella enterica infections are controlled by the use of antibiotics. Nevertheless, the use of antibiotics for prophylactics and treatment of these infections especially anarchically contribute to antimicrobial resistance. Berghichen et al. (2018) noted a massive use of antibiotics and mostly used without adhering to their principles of application in Algeria. Resistance of bacteria to multiple antimicrobials is a concern to public health and scientific studies (Raja et al., 2017; van den Honert et al., 2018; WHO, 2018; Adzitey et al., 2019; Berghiche et al., 2019; Tay et al., 2019). This is so because, the use of antimicrobial drugs in veterinary medicine and animal husbandry may compromise human health if resistant bacteria develop in animals and are transferred to humans through the food chain and environment (McNulty et al., 2016). The evolution and development of multiple drug resistant pathogenic 
microorganisms has necessitated the search for new source of antimicrobial substances, including plant metabolites (Nostro et al., 2000). Hence, the assessment of the efficacy of plant-based drugs in traditional veterinary medicine is of paramount importance because these drugs educe few side effects, affordable and easily available. Sofowora (2003) reiterated that the use of traditional veterinary medicine may be due to its low cost, availability and ease of application compared to modern veterinary medicine. Many plants have beneficial multifunctional aspects which are derived from their specific bioactive components (Mothana and Lincleqist, 2005; Kar and Bera, 2018). Many plants have also been subjected to pharmacological test, and a substantial number of new antibiotics have been developed from them (Mothana and Lincleqist, 2005).

Aloe vera is an ancient plant with its origin in African continent and has been reported to have beneficial effects on the growth performance, gut microflora, hematological characteristics, carcass characteristics and immune response of poultry (Kaithwas et al., 2008; Yadav, 2017; Kar and Bera, 2018). It can survive under a wide variety of conditions and has been shown to have many medicinal and antibiotic properties (Christaki and Florou-Paneri, 2010; Kar and Bera, 2018). Jain et al. (2016) reported that Aloe vera gel has been used for management of various infections since ancient times as it has anti-inflammatory, anti-microbial, and immune-boosting properties. Guinea fowls (Numida meleagris) in Ghana are dominated by local or traditional breeds reared mostly in Northern part of Ghana. The meat of guinea fowls is cherished and relished by many Ghanaians (Adzitey et al., 2015). Nonetheless, they are kept mainly under the extensive and semi-extensive systems, and are exposed to a variety of bacteria during scavenging (Teye et al., 2000; Adzitey et al., 2015) The gastrointestinal tracts of animals are well known to harbor bacteria such as Campylobacter spp., Clostridium spp., Escherichia coli, Lactobacillus spp., Salmonella spp., Shigella spp. and Vibrio spp. Guinea fowls can feed on plants which may include Aloe vera during scavenging.

This study was conducted to determine the antibacterial effect of Aloe vera extracts on Escherichia coli and Salmonella enterica isolated from the gastrointestinal tract of guinea fowl.

\section{MATERIALS AND METHODS}

\section{Study area, sample collection and analysis}

This study was conducted at the Microbiology Laboratory (in the Spanish laboratory) of University for Development Studies, Nyankpala Campus, Ghana. Fresh Aloe vera plants (harvested from backyard garden) and the gastrointestinal tract (collected from slaughter slab) of 15 guinea fowls (Numida meleagris) were obtained from the Tamale metropolis. The gastrointestinal tracts were analyzed immediately upon reaching the laboratory for the presence of Escherichia coli and Salmonella enterica following the procedures in the bacteriological analytical manual of the FDA-USA (Feng et al., 2017; Andrews et al., 2018).

\section{Isolation and confirmation of Escherichia coli and Salmonella enterica}

For the isolation of Escherichia coli, one g of gastrointestinal tract content was pre-enriched in $10 \mathrm{ml}$ of Buffered Peptone Water (BPW) and incubated at $37^{\circ} \mathrm{C}$ for $18-24 \mathrm{~h}$. After which, the aliquots were plated on Levine EosinMethylene Blue Agar and incubated again at $37^{\circ} \mathrm{C}$ for $24 \mathrm{~h}$. For Salmonella enterica, aliquots from BPW were further enriched in Rappaport Vassiliadis (RV) and Selenite (SN) Broths. Samples in RV broth were incubated at $42^{\circ} \mathrm{C}$ for $24 \mathrm{~h}$ while those in SN broth were incubated at $37^{\circ} \mathrm{C}$ for $24-48 \mathrm{~h}$. After incubation, the aliquots from RV and SN broths were plated on xylose lysine deoxycholate and brilliant green agar, and incubated at $37^{\circ} \mathrm{C}$ for $24 \mathrm{~h}$. Presumptive Escherichia coli and Salmonella enterica were purified on trypticase soy agar (incubated at $37^{\circ} \mathrm{C}$ for $24 \mathrm{~h}$ ) and confirmed using the appropriate biochemical tests as stated by Feng et al. (2017) and Andrews et al. (2018), and serological tests using Escherichia coli and Salmonella latex agglutination test kits (Oxoid, Basingstoke, UK). All incubations were done under aerobic conditions and all media used were purchased from Oxiod, Basingstoke, UK.

\section{Extraction of Aloe vera gel extract}

The Aloe vera gel extract was prepared according to Thiruppathi et al. (2010). Briefly, the Aloe vera gel was extracted under aseptic condition, dried in an oven at $70^{\circ} \mathrm{C}$ for $24 \mathrm{~h}$ and then milled into powder. $10 \mathrm{~g}$ of the oven-dried Aloe vera gel powder was suspended in $50 \mathrm{ml}$ of $80 \%$ ethanol and kept on a shaker for $24 \mathrm{~h}$ for proper dissolution. This was then filtered through Whitman paper no. 1 and allowed to evaporate in an oven at $80^{\circ} \mathrm{C}$ for $24 \mathrm{~h}$. The dried extract was dissolved in Dimethyl Sulfoxide (DMSO) and stored in the refrigerator at $4^{\circ} \mathrm{C}$ for further uses.

\section{Preparation of standard concentrations of Aloe vera extract and bacteria inocula}

200, 100 and $50 \mathrm{mg}$ of Aloe vera gel powder were separately dissolved in one $\mathrm{ml}$ of DMSO. Single colony of pure cultures of Escherichia coli and Salmonella enterica were isolated and grown in Trypticase Soy Broth (TSB) and incubated at $37^{\circ} \mathrm{C}$ for $24 \mathrm{~h}$. Then, the concentration was adjusted to $0.5 \mathrm{McF}$ arland turbidity using sterile TSB. 


\section{Antibiotic susceptibility test using standard antibiotics and Aloe vera gel extract}

These were done using the disc diffusion method of Bauer-Kirby (1966). For the conventional standard method, the isolates (in TSB adjusted to 0.5 McFarland turbidity) were swabbed onto Mueller-Hinton (MH) agar using a sterile cotton swab. Eight different standard antibiotics, notably: Ampicillin (Amp) $10 \mu \mathrm{g}$, Chloramphenicol (C) $30 \mu \mathrm{g}$, Gentamicin (Cn) $10 \mu \mathrm{g}$, Ceftriaxone (Cro) $30 \mu \mathrm{g}$, Ciprofloxacin (Cip) $5 \mu \mathrm{g}$, Erythromycin (E) $15 \mu \mathrm{g}$, sulfamethoxazole/Trimethoprim (Sxt) $22 \mu \mathrm{g}$, and Tetracycline (Te) $30 \mu \mathrm{g}$ were placed on the HM agar at a distance to prevent overlapping of the inhibition zones. The $\mathrm{MH}$ agar was incubated aerobically at $37^{\circ} \mathrm{C}$ for $24 \mathrm{~h}, 48 \mathrm{~h}$ and $72 \mathrm{~h}$, and the inhibition zones measured in millimeters $(\mathrm{mm})$. The inhibition zones were interpreted according to the Clinical Laboratory Standard Institute (2014).

For the antibacterial test using Aloe vera gel extracts at different concentrations, blank antibiotic discs purchased from Oxoid, Basingstoke, UK were individually impregnated with different concentrations (200mg, 100mg and 50mg) of the Aloe vera extract, and were placed on the surface of the $\mathrm{MH}$ agar which has been inoculated with the isolates. Then, it was incubated at $37^{\circ} \mathrm{C}$ for $24 \mathrm{~h}, 48 \mathrm{~h}$ and $72 \mathrm{~h}$, and the inhibition zones measured in mm. All the antibiotic discs were placed at a distance to avoid overlapping of inhibition zones.

\section{Statistical analysis}

The data obtained in this study were analyzed using One-way ANOVA of the GenStat Release 12 Edition. Significant differences were determined at $95 \%(\mathrm{P}<0.05)$

\section{RESULTS}

\section{Prevalence of Escherichia coli and Salmonella enterica in gastrointestinal tract of guinea fowls}

The prevalence of Escherichia coli and Salmonella enterica in the gastrointestinal tract (gut) of the guinea fowl was $100 \%(15 / 15)$ and $40 \%(6 / 15)$, respectively.

\section{Escherichia coli and Salmonella enterica sensitivity tests}

The antibiotic resistance of three randomly selected Escherichia coli isolates is shown in table 1. Out of the three Escherichia coli isolates subjected to antibiotic susceptibility test, $37.5 \%$ were susceptible, $45.8 \%$ were resistant and $16.7 \%$ were intermediate resistant. Escherichia coli isolates were $100 \%$ resistant to Amp and Te at $24 \mathrm{~h}$ but not at $48 \mathrm{~h}$ and $72 \mathrm{~h}$. The Escherichia coli isolates were all susceptible to Cip (100\%) at all incubation periods (24, 48 and $72 \mathrm{~h})$. The Escherichia coli isolates also exhibited some intermediate resistances to Cro (at $24 \mathrm{~h}$ ), G (at $24 \mathrm{~h}$ ), Sxt (at $24 \mathrm{~h}$ ) and $\mathrm{E}$ (at 24, 48 and $72 \mathrm{~h}$ ). Resistance to $\mathrm{C}$ and Cro were not the same at 24, 48 and $72 \mathrm{~h}$ of incubation whilst it was the same for Sxt and E. The antibiotic activity of the Salmonella enterica isolates is presented in table 2. Overall, $70.8 \%$ of the Salmonella enterica isolates were susceptible, $29.2 \%$ were resistant and none exhibited intermediate resistant. All the Salmonella enterica isolates were susceptible to gentamicin at $24 \mathrm{~h}, 48 \mathrm{~h}$ and $72 \mathrm{~h}$. With the exception of Sxt and Te, the results for all the antibiotics against the Escherichia coli isolates were the same for all the incubation periods. Results for Sxt and Te were however, the same at $48 \mathrm{~h}$ and $72 \mathrm{~h}$ of incubation.

\section{Evaluation of antibacterial activity of Aloe vera extracts against Escherichia coli and Salmonella enterica}

The exhibition zones for the Escherichia coli isolates ranged between 9.10 to $12.23 \mathrm{~mm}$ for Escherichia coli isolate GIT1, 7.8 to $8.57 \mathrm{~mm}$ for Escherichia coli isolate GIT2 and 7.43 to $17.23 \mathrm{~mm}$ for Escherichia coli isolate GIT7 (Table 3). Inhibition zones for the Escherichia coli isolates (GIT1, GIT2 and GIT3) did not significantly differ (P $>0.05)$ at 50 $\mathrm{mg} / \mathrm{ml}$ and $200 \mathrm{mg} / \mathrm{ml}$ but significantly differed $(\mathrm{P}<0.05)$ at $100 \mathrm{mg} / \mathrm{ml}$. The inhibition zones for $50 \mathrm{mg} / \mathrm{ml}, 100 \mathrm{mg} / \mathrm{ml}$ and $200 \mathrm{mg} / \mathrm{ml}$ Aloe vera gel extract ranged between 7.87 to $12.23 \mathrm{~mm}, 8.53$ to $17.23 \mathrm{~mm}$ and 7.43 to $10.67 \mathrm{~mm}$, respectively. The results in table 3 indicated that Aloe vera extracts at $100 \mathrm{mg} / \mathrm{ml}$ was the most effective in controlling of Escherichia coli isolates. At $100 \mathrm{mg} / \mathrm{ml}$, most of the Escherichia coli isolates produced higher inhibition zones compared to other concentrations $(50 \mathrm{mg} / \mathrm{ml}$ and $200 \mathrm{mg} / \mathrm{ml}$ ).

The exhibition zones for the Salmonella enterica ranged between 5.3 to $12.57 \mathrm{~mm}$ for Salmonella enterica isolate GIT9, 0 to $7.8 \mathrm{~mm}$ for Salmonella enterica isolate GIT10 and 4.2 to $9.0 \mathrm{~mm}$ for Salmonella enterica isolate GIT15 (Table 4). Also in table 4, inhibition zones for the Salmonella enterica isolates (GIT9, GIT10 and GIT15) differed significantly $(\mathrm{P}<0.05)$ at $50 \mathrm{mg} / \mathrm{ml}$ and $200 \mathrm{mg} / \mathrm{ml}$ but not at $100 \mathrm{mg} / \mathrm{ml}(\mathrm{P}>0.05)$. The inhibition zones for $50 \mathrm{mg} / \mathrm{ml}$, $100 \mathrm{mg} / \mathrm{ml}$ and $200 \mathrm{mg} / \mathrm{ml}$ Aloe vera gel extract ranged between 7.13 to $12.57 \mathrm{~mm}, 4.2$ to $6.7 \mathrm{~mm}$ and 0 to $9.23 \mathrm{~mm}$, respectively. The results in table 4 revealed that Aloe vera gel extracts at $50 \mathrm{mg} / \mathrm{ml}$ was effective in controlling Escherichia coli isolates. At $50 \mathrm{mg} / \mathrm{ml}$, most of the Salmonella enterica isolates produced higher inhibition zones $(\mathrm{P} \leq 0.05)$ compared to other concentrations $(100 \mathrm{mg} / \mathrm{ml}$ and $200 \mathrm{mg} / \mathrm{ml})$. 
Table 1. Percentage antibiotic activity of Escherichia coli isolated from gastrointestinal tract of guinea fowl at 24,48 and 72 hours in the Tamale Metropolis, Ghana

\begin{tabular}{|c|c|c|c|c|c|c|c|c|c|c|}
\hline \multirow[b]{2}{*}{ Antibiotics } & \multirow{2}{*}{$\begin{array}{c}\text { No. of } \\
\text { Isolates }\end{array}$} & \multicolumn{3}{|c|}{24 hours } & \multicolumn{3}{|c|}{48 hours } & \multicolumn{3}{|c|}{72 hours } \\
\hline & & $\mathrm{S}(\%)$ & $\mathrm{I}(\%)$ & $\mathrm{R}(\%)$ & $\mathrm{S}(\%)$ & $\mathrm{I}(\%)$ & $\mathrm{R}(\%)$ & $\mathrm{S}(\%)$ & $\mathrm{I}(\%)$ & $\mathrm{R}(\%)$ \\
\hline Ampicillin (AMP) & 3 & 0.00 & 0.00 & 100 & 0.00 & 33.3 & 66.7 & 0.00 & 33.3 & 66.7 \\
\hline Chloramphenicol (C) & 3 & 33.3 & 0.00 & 66.7 & 33.3 & 33.3 & 33.3 & 33.3 & 33.3 & 33.3 \\
\hline Ciprofloxacin (Cip) & 3 & 100 & 0.00 & 0.00 & 100 & 0.00 & 0.00 & 100 & 0.00 & 0.00 \\
\hline Ceftriaxone (Cro) & 3 & 33.3 & 33.3 & 33.3 & 66.7 & 0.00 & 33.3 & 66.7 & 0.00 & 33.3 \\
\hline Gentamicin $(\mathrm{Cn})$ & 3 & 66.7 & 33.3 & 0.00 & 100 & 0.00 & 0.00 & 100 & 0.00 & 0.00 \\
\hline Erythromycin (E) & 3 & 0.00 & 33.3 & 66.7 & 0.00 & 33.3 & 66.7 & 0.00 & 33.3 & 66.7 \\
\hline Sxt & 3 & 66.7 & 33.3 & 0.00 & 66.7 & 33.3 & 0.00 & 66.7 & 33.3 & 0.00 \\
\hline Tetracycline (Te) & 3 & 0.00 & 0.00 & 100 & 33.3 & 33.3 & 33.3 & 66.7 & 33.3 & 0.00 \\
\hline
\end{tabular}

No: number, S: susceptible, I: Intermediate, R: resistant, Sxt: Suphamethoxazole/trimethoprim.

Table 2. Percentage antibiotic activity of Salmonella enterica isolated from gastrointestinal tract of guinea fowl at 24,48 and 72 hours in the Tamale Metropolis, Ghana

\begin{tabular}{|c|c|c|c|c|c|c|c|c|c|c|}
\hline \multirow[b]{2}{*}{ Antibiotics } & \multirow[b]{2}{*}{$\begin{array}{c}\text { No. of } \\
\text { Isolates }\end{array}$} & \multicolumn{3}{|c|}{24 hours } & \multicolumn{3}{|c|}{48 hours } & \multicolumn{3}{|c|}{72 hours } \\
\hline & & $\mathrm{S}(\%)$ & I $(\%)$ & $\mathrm{R}(\%)$ & $\mathrm{S}(\%)$ & I $(\%)$ & $\mathrm{R}(\%)$ & $\mathrm{S}(\%)$ & $\mathrm{I}(\%)$ & $\mathrm{R}(\%)$ \\
\hline Ampicillin (AMP) & 3 & 66.7 & 0.00 & 33.3 & 66.7 & 0.00 & 33.3 & 66.7 & 0.00 & 33.3 \\
\hline Chloramphenicol (C) & 3 & 66.7 & 0.00 & 33.3 & 66.7 & 0.00 & 33.3 & 66.7 & 0.00 & 33.3 \\
\hline Ciprofloxacin (Cip) & 3 & 66.7 & 0.00 & 33.3 & 66.7 & 0.00 & 33.3 & 66.7 & 0.00 & 33.3 \\
\hline Ceftriaxone (Cro) & 3 & 66.7 & 0.00 & 33.3 & 66.7 & 0.00 & 33.3 & 66.7 & 0.00 & 33.3 \\
\hline Gentamicin $(\mathrm{Cn})$ & 3 & 100 & 0.00 & 0.00 & 100 & 0.00 & 0.00 & 100 & 0.00 & 0.00 \\
\hline Erythromycin (E) & 3 & 66.7 & 0.00 & 33.3 & 66.7 & 0.00 & 33.3 & 66.7 & 0.00 & 33.3 \\
\hline Sxt & 3 & 66.7 & 0.00 & 33.3 & 100 & 0.00 & 0.00 & 100 & 0.00 & 0.00 \\
\hline Tetracycline (Te) & 3 & 66.7 & 0.00 & 33.3 & 100 & 0.00 & 0.00 & 100 & 0.00 & 0.00 \\
\hline
\end{tabular}

No: number, S: susceptible, I: Intermediate, R: resistant, Sxt: Suphamethoxazole/trimethoprim. 
Table 3. Zones of inhibition by Aloe vera extract against the Escherichia coli isolated from gastrointestinal tract of guinea fowl at 24 , 48 and 72 hours in the Tamale Metropolis, Ghana

\begin{tabular}{|c|c|c|c|c|c|c|c|c|c|}
\hline \multirow{2}{*}{ E.coli isolates } & \multicolumn{3}{|c|}{24 hours } & \multicolumn{3}{|c|}{48 hours } & \multicolumn{3}{|c|}{72 hours } \\
\hline & $200 \mathrm{mg} / \mathrm{ml}$ & $100 \mathrm{mg} / \mathrm{ml}$ & $50 \mathrm{mg} / \mathrm{ml}$ & $200 \mathrm{mg} / \mathrm{ml}$ & $100 \mathrm{mg} / \mathrm{ml}$ & $50 \mathrm{mg} / \mathrm{ml}$ & $200 \mathrm{mg} / \mathrm{ml}$ & $100 \mathrm{mg} / \mathrm{ml}$ & $50 \mathrm{mg} / \mathrm{ml}$ \\
\hline GIT 1 & 9.13 & $9.10^{b}$ & 11.23 & 10.3 & $9.10^{\mathrm{b}}$ & 12.23 & 10.67 & $9.33^{b}$ & 12.33 \\
\hline GIT2 & 7.8 & $8.53^{\mathrm{b}}$ & 7.87 & 8.1 & $8.53^{\mathrm{b}}$ & 8.13 & 8.33 & $8.57^{\mathrm{b}}$ & 8.23 \\
\hline GIT7 & 7.43 & $14.43^{\mathrm{a}}$ & 9.2 & 9.2 & $17.10^{\mathrm{a}}$ & 10.37 & 9.67 & $17.23^{\mathrm{a}}$ & 10.3 \\
\hline SEM & 3.258 & 1.986 & 3.032 & 5.1 & 3.186 & 2.928 & 4.568 & 3.706 & 3.236 \\
\hline$P$ value & 0.577 & 0.002 & 0.164 & 0.704 & 0.003 & 0.081 & 0.616 & 0.006 & 0.113 \\
\hline
\end{tabular}

Escherichia coli: Escherichia coli, GIT: Gastrointestinal tract, The GIT 1, GIT2 and GIT7 were randomly selected from positive Escherichia coli isolates, SEM:

Standard Error of Means. Means with different superscript along the columns are different at $\mathrm{P} \leq 0.05$.

Table 4. Zones of inhibition by Aloe vera extract against the Salmonella enterica isolated from gastrointestinal tract of guinea fowl at 24,48 and 72 hours in the Tamale Metropolis, Ghana

\begin{tabular}{|c|c|c|c|c|c|c|c|c|c|}
\hline \multirow{2}{*}{ E.coli isolates } & \multicolumn{3}{|c|}{24 hours } & \multicolumn{3}{|c|}{48 hours } & \multicolumn{3}{|c|}{72 hours } \\
\hline & $200 \mathrm{mg} / \mathrm{ml}$ & $100 \mathrm{mg} / \mathrm{ml}$ & $50 \mathrm{mg} / \mathrm{ml}$ & $200 \mathrm{mg} / \mathrm{ml}$ & $100 \mathrm{mg} / \mathrm{ml}$ & $50 \mathrm{mg} / \mathrm{ml}$ & $200 \mathrm{mg} / \mathrm{ml}$ & $100 \mathrm{mg} / \mathrm{ml}$ & $50 \mathrm{mg} / \mathrm{ml}$ \\
\hline GIT 1 & $8.23^{\mathrm{a}}$ & 5.3 & $9.00^{\mathrm{a}}$ & $9.13^{\mathrm{a}}$ & 6.7 & $12.57^{\mathrm{a}}$ & $9.23^{\mathrm{a}}$ & 6.7 & $12.57^{\mathrm{a}}$ \\
\hline GIT2 & $0.00^{\mathrm{c}}$ & 4.3 & $7.13^{b}$ & $0.00^{\mathrm{b}}$ & 4.7 & $7.77^{\mathrm{b}}$ & $0.00^{\mathrm{b}}$ & 4.7 & $7.87^{\mathrm{b}}$ \\
\hline GIT7 & $6.67^{\mathrm{b}}$ & 4.2 & $7.67^{\mathrm{b}}$ & $8.23^{\mathrm{a}}$ & 4.6 & $7.77^{\mathrm{b}}$ & $9.00^{\mathrm{a}}$ & 4.8 & $7.80^{\mathrm{b}}$ \\
\hline SEM & 0.722 & 6.8 & 1.022 & 1.468 & 7.66 & 1.178 & 1.942 & 7.74 & 1.176 \\
\hline$P$ value & 0.001 & 0.938 & 0.026 & 0.001 & 0.83 & 0.001 & 0.001 & 0.85 & 0.001 \\
\hline
\end{tabular}

GIT: Gastrointestinal tract, The GIT 9, GIT10 and GIT15 were randomly selected from positive Salmonella enterica isolates, SEM: Standard Error of Means. Means with different superscript along the columns are different at $\mathrm{P} \leq 0.05$ 


\section{DISCUSSION}

Escherichia coli and Salmonella enterica were found in the gastrointestinal tract (gut) of the guinea fowls. It is common to find these bacteria in the gastrointestinal tract of animals since it is a natural habit for microorganisms. However, they can pose problems to poultry and consequently humans when they are present in large numbers. Also, pathogenic Escherichia coli and Salmonella enterica strains can cause Escherichia coli and Salmonella infections, respectively. The presence of Escherichia coli and Salmonella enterica in the gastrointestinal tract of guinea fowls present opportunity for cross contamination unto carcasses during processing. Adzitey et al. (2015) found Escherichia coli and Salmonella enterica in fresh and smoked guinea fowls and attributed them to poor processing during dressing and cross contamination from their natural habitat. Kilonzo-Nthenge et al. (2018) isolated Salmonella enterica from 23\% of whole carcass rinses of guinea fowl.

This study revealed that the Escherichia coli isolates exhibited overall susceptibility (37.5\%), resistant (45.8\%) and intermediate resistant $(16.7 \%)$. There were some changes in resistant patterns with incubation time which was observed for ampicillin, chloramphenicol, ceftriaxone, gentamicin and tetracycline. Bacteria can develop resistance to antibiotics via mutation or the acquisition of resistant genes from other bacteria (Wintersdorff et al., 2016). Furthermore, intermediate resistances were found at $24 \mathrm{~h}, 48 \mathrm{~h}$, and/or $72 \mathrm{~h}$ for all the antibiotics except ciprofloxacin. Any isolate that exhibited intermediate resistant has the tendency to become resistant (Adzitey et al., 2016; Adzitey, 2018). KilonzoNthenge et al. (2008) reported that Escherichia coli isolated from guinea fowls were resistant to ampicillin but susceptible to ciprofloxacin, erythromycin and tetracycline, which was similar to this present work.

In this study, most of the Salmonella enterica isolates were susceptible ( $\geq 66.8 \%)$ to the eight different antibiotics tested. Intermediate resistant was not observed for the Salmonella enterica isolates, however, some of the Salmonella enterica isolates exhibited 33.3\% resistance. All the Salmonella enterica isolates were susceptible to Cn. The reason for the development of resistant among pathogens including Salmonella enterica have been linked to the indiscriminate use of antibiotics for therapeutic and growth purposes in animals (Wintersdorff et al., 2016). Salmonella enterica species isolated from guinea fowls were resistant to Amp and Te, but susceptible to Cip and E (Kilonzo-Nthenge et al., 2008). In this study $33.3 \%$ resistance was found at $24 \mathrm{~h}$ for Amp and Te, but $66.7 \%$ susceptibility for Cip and $\mathrm{E}$ at $24 \mathrm{~h}$. At $48 \mathrm{~h}$ and $72 \mathrm{~h}$, all the Salmonella enterica isolates were susceptible to Sxt and Te. These results suggested that the mentioned antibiotics require more than $24 \mathrm{~h}$ to be bactericidal for Salmonella enterica isolates examined in this study.

The antibacterial activity of Aloe vera gel extract was investigated against Escherichia coli and Salmonella enterica isolates of guinea fowl gastrointestinal tract origin using the disc diffusion method. The results obtained revealed that Aloe vera gel extract had antibacterial activities. Isolates of Escherichia coli treated with $100 \mathrm{mg} / \mathrm{ml}$ concentration of Aloe vera gel extract caused the highest overall inhibition zone than those treated with $50 \mathrm{mg} / \mathrm{ml}$ and $200 \mathrm{mg} / \mathrm{ml}$ of Aloe vera gel extract. Irshad et al. (2011) reported that Aloe vera extract produced an average inhibition zone of $2 \mathrm{~mm}$ against Escherichia coli. Ferro et al. (2003) found an inhibition zone of $12.66 \mathrm{~mm}$ for Escherichia coli isolates. The inhibition zones in this study were generally higher than the findings of Irshad et al. (2011) and had some similarity with findings of Ferro et al. (2003). Irshad et al. (2011) reported that that Aloe vera extracted using acetone exhibited stronger activity against Escherichia coli as compared to aqueous or ethanol extracts. Ferro et al. (2003) reported that sap water extract was more effective than leaf extract against Escherichia coli. In this study, Aloe vera gel extract exhibited antibacterial activity against all the Escherichia coli isolates, and was the highest at $100 \mathrm{mg} / \mathrm{ml}$.

The growth of Salmonella enterica isolates was inhibited at $50 \mathrm{mg} / \mathrm{ml}$ than those treated with $100 \mathrm{mg} / \mathrm{ml}$ and 200 $\mathrm{mg} / \mathrm{ml}$ of Aloe vera gel extracts across $24 \mathrm{~h}, 48 \mathrm{~h}$, and $72 \mathrm{~h}$ of incubation. Qadir et al. (2013) found that the best concentration of Aloe vera water extract inhibition for Escherichia coli was at $75 \%$, with inhibition zone of $9.75 \pm 0.25$ $\mathrm{mm}$. Inhibition zones lower or higher than $9.75 \mathrm{~mm}$ were found in this study. Jonson et al. (2011) examined 35 clinical Salmonella enterica isolates and reported that, 17 isolates had inhibition zone of 7 to $32 \mathrm{~mm}$ in $0.007 \mathrm{mg} / \mathrm{ml}$ of the extract. The highest zone of inhibition produced by the Aloe vera gel extract in this study against Salmonella enterica isolate was $12.27 \mathrm{~mm}$ which was lower than the $32 \mathrm{~mm}$ reported by Jonson et al. (2011).

Kaithwas et al. (2008) studied the antimicrobial activity of Aloe vera gel by using disc diffusion method and reported that, the gel was effective against Salmonella enterica. Kar and Bera (2018) indicated that, the Aloe vera gel is rich in variety of secondary metabolites, such as anthraquinones glycosides, glycoproteins, gamma-lanoline acid, prostaglandins and mucopolysaccharides, which are mainly responsible for its antimicrobial activity. In this study, there were differences in the antimicrobial activities of the Aloe vera gel extract. Azwanida (2015) revealed that differences in antibacterial activity of Aloe vera plant extracts can be attributed to the age of the plant, physical factors such as temperature, light, water, time of harvesting of plant and drying method used before the extraction process.

\section{CONCLUSION}

This study confirmed the potential of Aloe vera gel extract as an antibacterial agent in poultry farming. Aloe vera gel extracts can be used as prophylactic antibiotics to reduce over dependence on conventional antibiotics that can lead to the 
development of resistant strains. It is recommended that, toxicity studies of the Aloe vera gel extract should be done to determine the safety indices of the extracts. Clinical trials should also be carried out to explore the potential of Aloe vera extracts in the treatment of bacterial infectious diseases of poultry.

\section{DECLARATIONS}

\section{Competing interests}

All authors declare that they have no conflict of interest.

\section{Author's contribution}

Adzitey F, Udoka JU and Agbolosu AA conceived and designed the experiment. Adzitey F and Udoka JU performed the experiment. Adzitey F and Agbolosu AA analyzed and wrote the manuscript. All authors read and approved this manuscript.

\section{Concept to publish}

All authors gave their informed consent prior to their inclusion in the study.

\section{REFERENCES}

Adzitey F, Assoah-Peprah P and Teye GA (2019). Whole genome sequencing of Escherichia coli isolated from contaminated meat samples collected from the Northern Region of Ghana revealed the presence of multidrug resistant genes. Journal of Global Antimicrobial Resistance, In Press, DOI:https://doi.org/10.1016/j.jgar.2019.03.014.

Adzitey F (2018). Antibiotic resistance of Escherichia coli and Salmonella enterica isolated from cabbage and lettuce samples in Tamale metropolis of Ghana. International Journal of Food Contamination, 5:7. DOI: https://doi.org/10.1186/s40550-018-0068$\mathrm{z}$.

Adzitey F, Ashiagbor CKN and Abu H (2016). Prevalence and antibiotic susceptibility of Salmonella enterica from water sources in Tamale, Ghana. International Journal of One Health, 2: 24-28. DOI: https://doi.org/10.14202/IJOH.2016.24-28.

Adzitey F, Teye GA and Anachinaba IA (2015). Microbial quality of fresh and smoked guinea fowl meat sold in the Bolgatanga Municipality, Ghana. Asian Journal of Poultry Science, 9: 165-171. DOI: https://doi.org/10.3923/ajpsaj.2015.165.171.

Andrews WH, Wang H, Jacobson A and Hammack T (2018). Bacteriological Analytical Manual (BAM), Chapter 5: Salmonella enterica. Available at: https://www.fda.gov/food/laboratory-methods-food/bacteriological-analytical-manual-bam-chapter-5Salmonella enterica. Accessed on 18 February, 2018.

Azwanida NN (2015). A Review on the extraction methods use in medicinal plants, principle, strength and limitation. Medical Aromatic Plants, 4:196. DOI: https://doi.org/10.4172/2167-0412.1000196.

Bauer AW, Kirby WM, Sherris JC and Turck M (1966). Antibiotic susceptibility testing by a standardized single disk method. America Journal of Clinical Pathology, 45: 493-496. DOI: https://doi.org/10.1093/ajcp/45.4_ts.493.

Berghiche A, Khenenou T and Labiad I (2019). A Meta-Analysis on antibiotic residues in meat of broiler chickens in developing countries. Journal of World's Poultry Research, 9: 89-97.

Berghiche A, Khenenou T and Labiad I (2018). Antibiotics resistance in broiler chicken from the farm to the table in Eastern Algeria. Journal of World's Poultry Research, 8: 95-99.

Christaki EV and Florou-Paneri PC (2010). Aloe vera: a plant for many uses. Journal of Food, Agriculture and Environment, 8: $245-$ 249.

Clinical and Laboratory Standards Institute (2014). Performance Standards for Antimicrobial Susceptibility Testing; Twenty-Fourth Informational Supplement, M100-S24, 34: 1. Available at: CLSIM100-24-2014\%20(1).pdf. Accessed on 18 February, 2017.

Feng P, Weagant SD, Grant MA and Burkhardt W (2017). Bacteriological Analytical Manual (BAM), Chapter 4: Enumeration of Escherichia coli and the coliform bacteria. Available at: https://www.fda.gov/food/laboratory-methods-food/bam-4enumeration-escherichia-coli-and-coliform-bacteria.

Ferro VA, Bradbury F, Cameron P, Shakir E, Rahman SR and Stimson WH (2003). In vitro susceptibilities of Shigella flexneri and Streptococcus pyogenes to inner gel of Aloe barbadensis miller. Antimicrobial Agents Chemotherapy, 47:1137-1139.

Johnson DB, Shringi B, Patidar DK, Chalichem NSS and Javvadi AK (2011). Screening of antimicrobial activity of alcoholic and aqueous extract of some indigenous plants. Indo-Global Journal of Pharmaceutical Sciences, 1: 186-193.

Irshad S, Butt M and Younus H (2011). In-vitro antibacterial activity of Aloe Barbadensis Miller (Aloe Vera). International Research Journal of Pharmaceuticals, 1: 59-64.

Kaithwas G, Kumar A, Pandey H, Acharya AK, Singh M, Bhatia D and Mukerjee A (2008). Investigation of comparative antimicrobial activity of Aloe vera gel and juice. Pharmacologyonline, 1: 239-243.

Kar K and Bera TK (2018). Phytochemical constituents of Aloe vera and their multifunctional properties: a comprehensive review. International Journal of Pharmaceutical Sciences and Research, 9: 1416-1423.

Kilonzo-Nthenge A, Nahashon SN, Chen F and Adefope N (2008). Prevalence and antimicrobial resistance of pathogenic bacteria in chicken and guinea fowl. Poultry Science, 87: 1841-1848. DOI: http://doi.org/10.3382/ps.2007-00156.

McNulty K, Soon JM, Wallace CA and Nastasijevic I (2016). Antimicrobial resistance monitoring and surveillance in the meat chain: A report from five countries in the European Union and European Economic Area. Trends Food Sciences and Technology, 58: 1-13. DOI: https://doi.org/10.1016/j.tifs.2016.09.010. 
Mothana RA and Lincleqist V (2005). Antimicrobial activity of some medicinal plants of the island Soqotra. Journal of Ethnopharmacology, 96: 177-181. DOI: http://doi.org/10.1016/j.jep.2004.09.006.

Nolan LK, Barnes HJ, Vaillancourt JP, Abdul-Aziz T, Logue CM, Swayne DE, Glisson JR, McDougald LR, Nolan LK, Suarez DL and Nair V (2013). Colibacillosis, diseases of poultry. USA Iowa State Press, pp. 751-805.

Nostro A, Germano MP, Angelo V, Marino A and Cannatelli MA (2000). Extraction methods and bio autography for evaluation of medicinal plant antimicrobial activity. Letters in Applied Microbiology, 30: 379-384.

Qadir FA, Sabr ZN and Sabr DR (2013). Effects of pomegranate, sumac, and Aloe vera extracts on Escherichia coli, Staphylococcus aureus, and Citrobacter isolated from urinary tract infection. Egypt Journal of Experimental Biology, 9: 41-48.

Raja Arief Deli RN and Adzitey F (2017). Prevalence and antibiotic resistance of Salmonella serovars isolated from spent hens and its environmental samples in Penang and Kedah, Malaysia. Journal Tropical Agriculture and Food Science, 45: 37-50.

Schepop LV (2017). Salmonellosis in poultry. Available at: https://www.viv.net/articles/blog/salmonellosis-in-poultry.

Sofowora A, Ogunbodede E and Onayade A (2013). The role and place of medicinal plants in the strategies for disease prevention. African Journal of Traditional, Complementary and Alternative Medicines, 10: 210-229. DOI: http://doi.org/10.4314/ajtcam.v10i5.2.

Tay MYF, Adzitey F, Sultan SA, Tati JM, Seow KLG and Schlundt J (2019). Whole-Genome sequencing of nontyphoidal Salmonella enterica enterica isolates obtained from various meat types in Ghana. Microbial Resource Announcement, 8 (15): 33-19. DOI: http://doi.org/10.1128/MRA.00033-19.

Teye GA and Adam M (2000). Constraints to guinea fowl production in northern Ghana: A case study of the Damongo area. Ghana Journal of Agricultural Science, 33: 153-157. DOI: http://doi.org/10.4314/gjas.v33i2.1864.

Thiruppathi S, Ramasubramanian V, Sivakumar T and Thirumalai A (2010). Antimicrobial activity of Aloe vera (L) Burm. F. against pathogenic microorganism. Journal of Biosciences and Research, 1: 251-258.

Van den Honert MS, Gouws PA and Hoffman LC (2018). Importance and implications of antibiotic resistance development in livestock and wildlife farming in South Africa: A Review. South African Journal of Animal Science, 48: 401-412. DOI: http://doi.org/10.4314/sajas.v48i3.1.

Wintersdorff CJH, Penders J, Van Niekerk JM, Mills ND, Majumder S, Van Alphen LB, Savelkoul PHM and Wolffs PFG (2016). Dissemination of antimicrobial resistance in microbial ecosystems through horizontal gene transfer. Frontiers in Microbiology, 7:1-10. DOI: http://doi.org/10.3389/fmicb.2016.00173.

World Health Organization (WHO) (2018). Antimicrobial resistance. Available at: https://www.who.int/news-room/factsheets/detail/antimicrobial-resistance. Accessed on 7 March, 2019.

Yadav DP (2017). Aloe vera as a feed additive in broiler chicken production: A review. International Journal of Veterinary Sciences and Animal Husbandry, 2:30-38. 